$$
\begin{gathered}
x_{1}=\left\{\begin{array}{c}
(3 a+2 b) \cos 36^{\circ}, ; \text { 为奇数; } \\
0 \quad \text { 其它. } \\
y_{i}=i(3 a+2 b) \sin 36^{\circ} .
\end{array}\right. \\
x_{i}^{\prime}=\left\{\begin{array}{cc}
x_{0}^{\prime}+x_{i}, & \text { 为奇数; } \\
x_{0}^{\prime} \quad \text { 其它. } \\
y_{i}=y_{0}+y_{i} .
\end{array}\right.
\end{gathered}
$$

若认定上层链中的圆(叠圆)遮盖着下层链中对 应的结点. 则本投影图的主要特征由下组定理描 述:

定理 1 在 $L_{i}\left(L_{i}\right), i=0, \pm 1, \pm 2, \cdots$ 轴 上, 从点 $\left(x_{i}, y_{i}\right)\left(\left(x_{i}^{\prime}, y_{i}^{\prime}\right)\right)$ 算起, 沿正方向结点分 布服从 Fibonacci 排列.

定理 2 对于 $j=0, \pm 1, \pm 2, \cdots$ 和 $n>3$, 设 $C_{\mathbf{i}, 0}$ 是 $L$, 轴上第 $n$ 个圆 $C_{i}^{*}$ 的圆心. 若 $C_{i}^{*}$ 与
$L_{j}$ 轴上其它圆分离，则在以 $C_{i, 0}$ 为心, $a 、 a+b$, $2 a+b$ 为半径的同心圆周上, 各以同样的方位均布 着 10 个结点.

定理 3 对于 $i=0, \pm 1, \pm 2, \cdots$ 和 $n>3$, 设 $C_{i, 0}^{*}, C_{i, 0}^{n+1}$ 是 $L$, 轴上第 $n$ 和 $n+1$ 个圆 $C_{i}^{*}$ 和 $C_{i}^{n+1}$ 之心. 则

$1^{0}$ 若 $C_{f}^{*} 、 C_{i}^{+1}$ 都是完整圆. 则在以 $C_{i, 0}^{*} 、 C_{i, 0}^{*+1}$ 为心 $a+b$ 为半径所画园形成的哑铃形圆周上, 分 布着 16 个结点。

$2^{0}$ 若 $C_{i}^{*}$ 重叠着 $C_{i}^{*+1}$ ：则在以 $C_{j, 0}^{*}, C_{i, 0}^{*+1}$ 为 心, $a+b$ 为半径所画圆形成的哑铃形圆周上,分布 着 14 个结点.

\section{李蒜闵乐泉 (北京钢铁学院数力系)}

\title{
河口海域阴离子表面活性剂的分析
}

沉积物的分析是基于用无水乙醇提取干样，提 取液可分別用乙基紫萃取光度法和原子吸收间接法 测定, 以直链烷基苯磺酸钠（LAS）为标准计算含 量. 前法是基于乙基紫阳离子与 AS 反应生成的离 子缔合物能被甲苯有效地萃取. 分取少量乙醇提取 液 (如 $5 \mathrm{ml}$ ) 可直接加入到水-甲苯 (水相约 $30 \mathrm{ml}$ $5 \mathrm{ml}$ 甲苯) 萃取体系中，一次萃取即可进行光度测 定, 萃取时水相合适的 $\mathrm{pH}$ 为 3.4-6.3, 有色化合 物萃取液的吸收峰在 $610-615 \mathrm{~nm}$ 处, 灵敏度 8 约 为 $8 \times 10^{4}$. 原子吸收法是基于 $\mathrm{AS}^{-}$在 $\mathrm{NaCl}$ 共存下 与 $\mathrm{Na}^{+}$形成离子对而被定量萃取人 MIBK 中, 通 过测定有机相中 Na 含量而间接定量. 样品的提取 液经蒸除乙醇并使待测物转入 $1 \% \mathrm{NaCl}$ 水溶液中, 再进行卒取火焰原子吸收测定, 测定的精密度良好. 沉积物中的大量无机盐不干扰上述方法的测定. 光
度法测得值较原子吸收法为高, 但河口区不同类型 和站位之样品两法分析的结果相关性密切 $(r=$ $0.96)$, 且所得的区域含量分布模式的趋势一致.

海水分析亦采用原子吸收法, 方法是取水样 $200 \mathrm{ml}$, 可直接加人 MIBK 进行卒取测定 (盐度 < $10 \%$ 的河口水可加 $\mathrm{NaCl}$ 使其浓度 $>1 \%$ ). 标准 曲线可用标准海水或 $\mathrm{NaCl}$ 溶液作为基体加入 $\mathrm{LAS}$ 配制, 盐度相当的标准海水和 $\mathrm{NaCl}$ 溶液制得的标 准曲线是相同的, 表明海水中的主要离子不干扰测 定, 盐度增大时空白值略有升高, 因而在盐度变化很 大的河口区取样分析时, 测定需进行盐度校正.

方法已用于海河口区水体及底质的调查研究、 为河口海域的环境特征提供了重要信息.

吴景阳李健博李云飞宋怀龙 (中国科学院海洋研究所，青岛）

\section{黑麦和水稻脯氦酸合成酶基因片段的克隆 及其对受体菌的影响}

生物有很多机制以适应渗透胁迫(干旱或高盐) 通常, 渗透调节剂是一类有机小分子. 从细菌, 藻 类、甲壳动物乃至高等植物，对渗透胁迫的反应往往 是在体内累积一定量的脯氨酸, 使细胞质的渗透压
强度与环境维持平衡. 因此, 脯氨酸合成酶基因的 表达调控可能与调渗作用有一定关系。

我们用营养缺陷互补的方法, 以 PAT153 DNA 为载体,脯氨酸缺陷菌 E. Coli HB101 (recA pro leu 
$\left.\mathrm{r}^{-} \mathrm{m}^{-}\right)$为受体克隆了黑麦和水稻脯氨酸合成酶基因 片段,分别得到了 3 及 25 个脯氮酸阳性转化体. 这 些转化体及再克隆得到的转化体都能在含脯氮酸的 拮抗物叫丁啶䍪酸的培养基中正常生长, 因此为 脯氮酸高产菌. 同时也说明了转化体脯氨酸阳性是 由于含有重组 DNA 而不是受体菌回变所致. 转化 体的插人片段均约为 $2.4 \mathrm{~kb}$ ，限制性内切酶图谱相 假，证明了这一基因片段的种间保守性。插人片段 与黑麦、水稳总 DNA 杂交,在 $2.4 \mathrm{~kb}$ 处可看到清晰 的杂交信号, 这就确认了这些片段来自植物. 从 HB101 和转化体的谷氨酸激酶活性比较看来, 转 化体的插入片段含有 proA 基因. 比较含 pAT153 的受体菌和转化体的总 RNA 分别与插人片段或 pAT153 DNA 杂交图谱可得到这一插人片段在转化 体中有转录物的结论.
对转化体进行了抗渗试验. 结果表明, 两种转 化体分别能在含 $15 \%$ 和 $20 \%$ 聚乙二醇(脱水剂, 通 常用作干旱程度的指标) 或 $0.55 \mathrm{~N} \mathrm{NaCl}$ 和 $0.70 \mathrm{~N}$ $\mathrm{NaCl}$ 的培养基中正常生长,而含载体的受体菌只能 抗 $5 \%$ 聚乙二醇或 $0.5 \mathrm{~N} \mathrm{NaCl}$. 进一步的实验表 明, 转化体在严重渗透胁迫下, 其胞内游离脯氨酸量 比正常情况增加一倍以上而插入基因片段的转录物 增加五倍以上。

这是第一次从高等真核生物, 无其是植物中分 离出与调渗作用有关的基因. 目前已在探索该基因 片段在植物细胞中的表达是否能提高植物细胞的抗 白政盐性. 本工作的细节即将另文发表.

陈受宜王 阁 劳为德 (中国科学院生物物理所,北京)

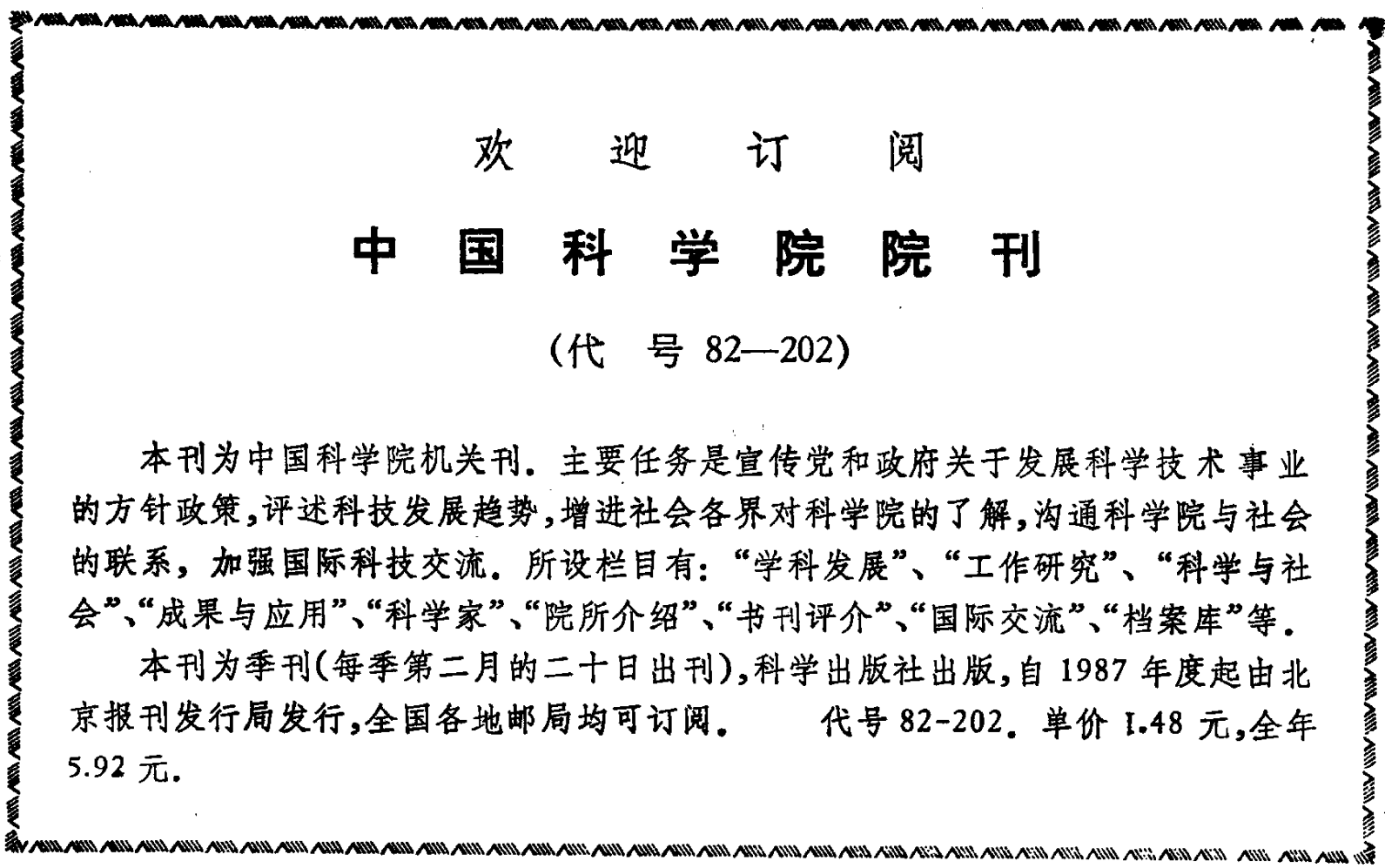

